\title{
Small-scale organism distributions and patterns of species diversity: evidence for positive interactions in an estuarine benthic community
}

\author{
Linda C. Schaffner \\ Virginia Institute of Marine Science, School of Marine Science, The College of William and Mary, Gloucester Point, \\ Virginia 23062, USA
}

\begin{abstract}
Previously, roles of physical factors and negative interactions in estuarine community organization have been emphasized. Recent studies suggest, however, that promotive processes can be important in structuring some soft-substrate communities. For this study, patterns of faunal abundance, small-scale (centimeters to decimeters) distribution, and species association are evaluated to assess the relative importance of positive species interactions or promotive processes in the regulation of an estuarine macrobenthic community. Based on living positions and habits, the dominant fauna collected in 70 box cores $\left(0.06 \mathrm{~m}^{2}\right)$ during a 13 mo period was classified into 5 major functional groups: (1) large tube and burrow builders, (2) small tube builders, (3) shallow burrowers, (4) deep burrowers, (5) epifaunal and tube or burrow coinhabitants. Positive correlations were more common (up to $52 \%$ of pairwise comparisons of abundance among groups of species) than negative correlations (up to $6 \%$ ). Highest percentages of positive correlations were observed among Group 4 species ( $53 \%$ ) and between Groups 1 and $4(38 \%)$. Highest percentages of negative correlations occurred between Groups 2 and 1 $(6 \%)$. The large tube-building polychaete Chaetopterus variopedatus directly influenced organism. abundance and species composition of near-surface fauna $(\leq 5 \mathrm{~cm})$. Number of species, diversity and faunal abundance were greater in samples that contained $C$. variopedatus than in samples that did not; most organisms exhibiting enhanced abundances were living on the tube above the sediment-water interface. The head-down feeding polychaete Macroclymene zonalis had no significant effect on species diversity or organism abundance in near-surface sediments. These patterns of species abundance and association suggest that biogenic alteration of the sedimentary environment, especially through sediment amelioration and the provision of substrate, modifies habitat availability and thereby provides a positive mechanism by which organism abundance and community structure are influenced.
\end{abstract}

\section{INTRODUCTION}

Identifying the factors and important processes governing population size and the structure of communities is a central problem in ecology. Studies of estuarine benthic communities have strongly emphasized the role of physical factors and negative interactions in community organization. Estuaries are typically characterized as physically controlled, unstable or unpredictable habitats which have relatively low species diversity and which are dominated by stresstolerant or short-lived opportunistic organisms (Burbanck et al. 1956, Sanders et al. 1963, Tenore 1972, Biggs \& Cronin 1981, Levinton 1982). The abilities of marine species to penetrate brackish waters are known to be limited by physiological intolerance to reduced salinity (Kinne 1964, Remane \& Schlieper 1971, Gainey
\& Greenberg 1977). Population dynamics in some brackish water communities are controlled by predation (Virnstein 1977, Holland et al. 1980, Ronn et al. 1988), negative adult-postlarvae interactions (Elmgren et al. 1986), disturbance (Tenore 1972, Boesch et al. 1976a, b, Santos \& Simon 1980, Holland et al. 1987) and recruitment success (Holland et al. 1987). Changes in community structure along the estuarine gradient are then attributed to coincident changes in the relative importance of these processes (e.g. Boesch 1977, Levinton 1982).

Increasingly, evidence derived experimentally from intertidal and shallow subtidal habitats shows that ecological processes which promote species success in marine soft-bottom communities are common and important phenomena (Woodin 1978, 1981, Gallagher et al. 1983, Peterson 1984, Reise 1985). Pattens of 
species distribution and association suggest that promotive interactions and processes also operate in deep, subtidal communities (e.g. Josefson 1981). The relative importance of promotive processes or interactions among species in most communities remains unclear. Existing information (reviewed in Reise 1985) suggests, however, that promotion is likely to be common where biogenic alteration of sediments facilitates 'accommodating' relationships among species (e.g. commensalism, mutualism), stabilizes sediments (e.g. worm reefs, seagrass beds), or alters sediment chemistry and near-bed hydrodynamics.

In this study, faunal abundance and small-scale horizontal and vertical distribution patterns are documented for a subtidal macrobenthic community in lower Chesapeake Bay, USA. These patterns are used to identify species associations and to evaluate the likely importance of positive or promotive processes in estuarine community organization.

\section{STUDY AREA}

The Wolf Trap study area (Fig. 1) is within the basin habitat (or 'baystem plains' sensu Wright et al. 1987), a broad, relatively flat, subtidal (ca 10 to $14 \mathrm{~m}$ ) expanse of silt and fine sand bottom that encompass about one fourth of the Chesapeake Bay south of $38^{\circ} \mathrm{N}$ latitude. Detailed physical characteristics of this habitat are presented in Boon et al. (1987). Schaffner et al. (1987a) and Wright et al. (1987). Recent studies demonstrate that bottom sediments in this area of Chesapeake Bay are

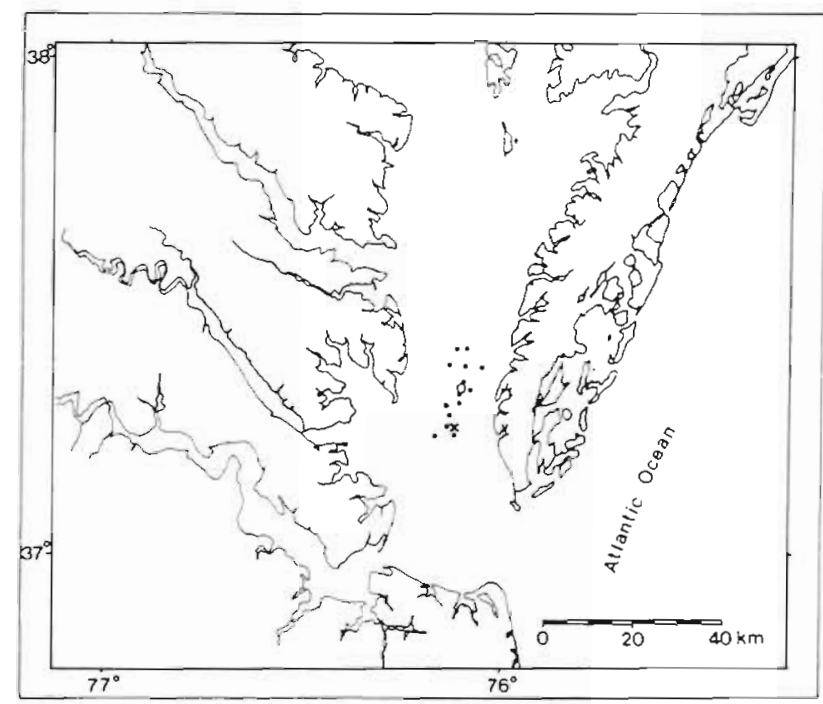

Fig. 1. Location of the study area within the Chesapeake Bay estuarine system, USA. (•) Box core station locations. (1) Area within which 'clustered' box cores were collected. $(x)$ Site of diver collections and observations. For further explanation see text primarily biogenically structured (Reinharz et al. 1982, Schaffner et al. $1987 \mathrm{a}$, Wright et al. 1987). Tubes, burrows and feeding voids account for most subsurface sediment modification (based on areal extent), including subduction of oxygenated waters to deeper sediment layers (Schaffner et al. 1987a, Diaz \& Schaffner 1988, unpubl.; Fig. 2a,b); tubes and fecal mounds are the dominant surface features (Wright et al. 1987, Diaz \& Schaffner 1988; Fig. 2c). Mean bottom salinities in the area studied range between 20 and $27 \mathrm{ppt}$, with typical differences of 2 to $3 \mathrm{ppt}$ from east to west and 3 to $4 \mathrm{ppt}$ differences from north to south (Stroup \& Lynn 1963). Average bottom temperatures range from a winter low of $4^{\circ} \mathrm{C}$ to a summer high of $25^{\circ} \mathrm{C}$ (Stroup \& Lynn 1963)

\section{METHODS}

Benthic sampling to determine community composition and species abundance was conducted during November 1983, February 1984, May 1984, August 1984 and November 1984. Fourteen fixed sampling locations were selected from an existing grid of 36 approximately evenly spaced stations (Fig. 1). Samples were collected using a spade box corer $\left(0.06 \mathrm{~m}^{2}\right)$. All box core samples were sectioned to include only sediments between 0 and $15 \mathrm{~cm}$ after preliminary analyses of samples collected to a depth of $20 \mathrm{~cm}$ or more (from November 1983) showed that $1 \%$ or less of the fauna was captured below $15 \mathrm{~cm}$ in the sediment column (Schaffner unpubl.). One core was collected for each location/date combination. During February 1984, an additional core from each sampling location was dissected as soon as possible after collection (generally within 1 or $2 \mathrm{~h}$ ) to uncover subsurface features and the living positions of resident fauna. During May and November 1984, 6 to 8 additional haphazardly located box cores collected from the central portion of the study area ('clustered' box cores; Fig. 1) were subsectioned $(0-2,2-5,5-10,10-15 \mathrm{~cm})$ for determination of species vertical distribution patterns. All box core samples were sieved on $500 \mu \mathrm{m}$ mesh screen in the field and fixed in formalin

The distribution and abundance patterns of macrobenthos $(\geq 250 \mu \mathrm{m})$ in a single box core from the study area ('clustered' box core site) that contained tubes of the polychaetes Chaetopterus variopedatus, Loimia medusa and Macroclymene zonalis were examined during May 1984. Sediments from 2 depth intervals $(0$ to $2 \mathrm{~cm}$ and 2 to $4 \mathrm{~cm}$ ) were partitioned with a contiguous $5 \times 8$ array of $2.5 \mathrm{~cm}^{2}$ cores ('core array samples') before being removed from the box core. Each core was fixed in formalin and subsequently sieved on $250 \mu \mathrm{m}$ mesh screen. The residue from each core was examined for tubes or other structures. 


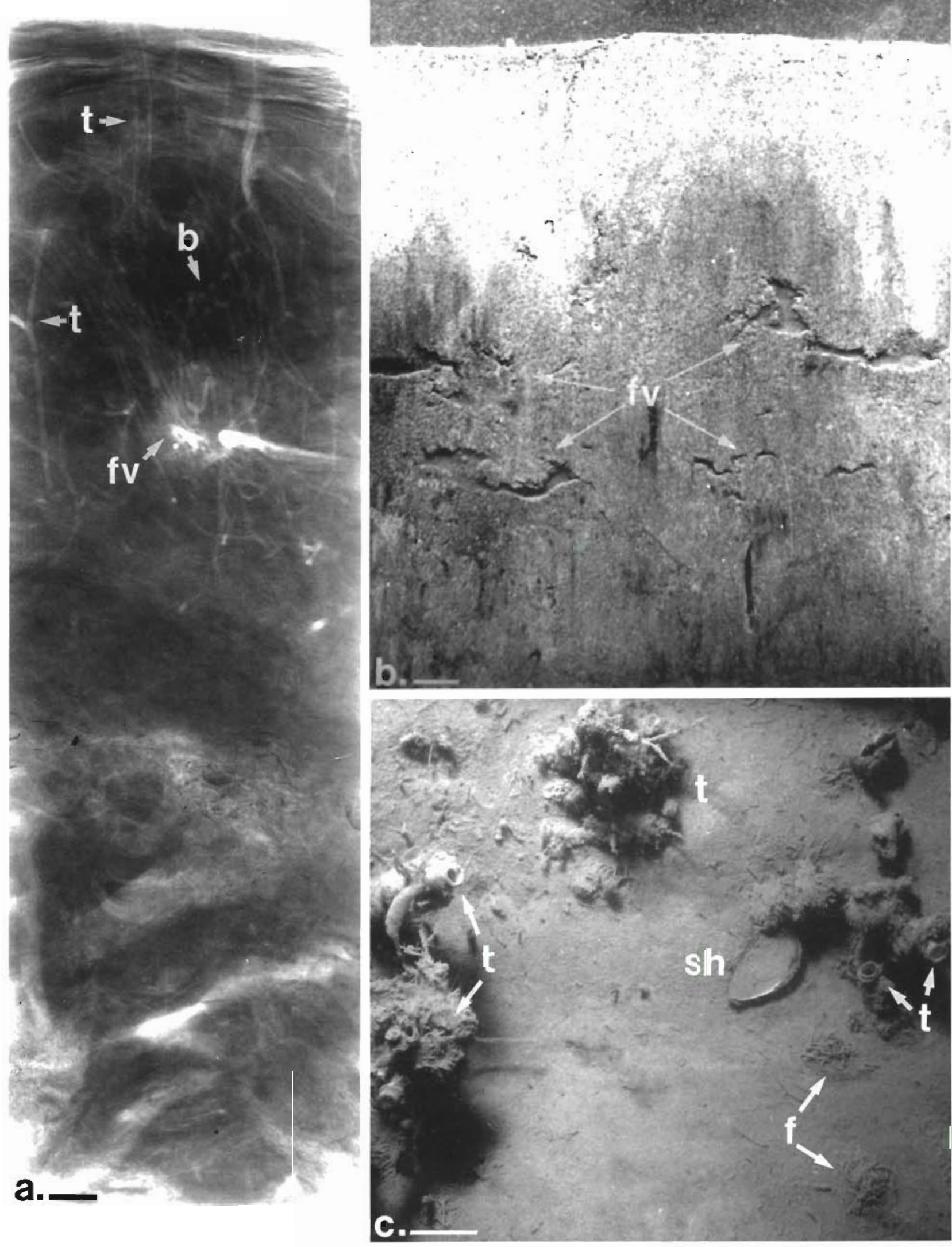

Fig. 2. (a) X-radiograph of a sediment core collected in February 1984. t: Macroclymene zonalis tubes; fv: feeding void; b: Notomastus latericeus burrow. (b) Sediment profile photograph taken during October 1984 showing network of Macroclymene zonalis feeding voids (fv). (c) Surface photograph taken during May 1985. t: tube top of Chaetopterus variopedatus with associated epifauna; f: fecal coil of Macroclymene zonalis; sh: shell. Scale bars $=1 \mathrm{~cm}$ 
Table 1. Abundance and depth distribution patterns of the 50 dominant taxa of the Wolf Trap study area. The grand mean number of individuals (SD) for the study ( $N=70$ cores) standardized to $\mathrm{m}^{2}$ areal units is given. Modal depth of occurrence and depth range data are from 'clustered' box core collections made during spring (Sp) and fall (F) 1984. np: no individuals present in collection. $\mathrm{N}=$ total number of sampled individuals for depth ranges. Major taxon for each species indicated as follows: (A) Amphipoda; (AN) Anthozoa; (B) Bivalvia; (E) Echinodermata; (G) Gastropoda; (H) Hemichordata; (N) Nemertinea; (O) Oligochaeta; (P) Polychaeta; (PH) Phoronida; (U) Urochordata. Living positions as follows: $B$, freely burrowing, infaunal; BS, burrow structure

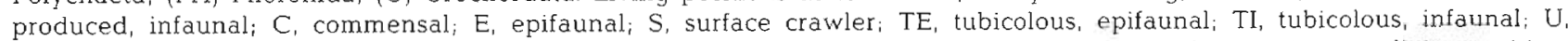
uncertain. Group membershjp categories are for Table 2 and are explained in text. For species with more than one living position, the dominant mode for this study is used for group assignment

\begin{tabular}{|c|c|c|c|c|c|c|c|}
\hline Taxon & $\begin{array}{c}\text { Grand } \\
\text { mean } \\
\text { ind. } m^{-2}\end{array}$ & $\begin{array}{l}\text { Living } \\
\text { position }\end{array}$ & Cruise & $N$ & $\begin{array}{l}\text { Modal } \\
\text { depth } \\
(\mathrm{cm})\end{array}$ & $\begin{array}{c}\text { Depth } \\
\text { range } \\
(\mathrm{cm})\end{array}$ & Group \\
\hline \multirow[t]{2}{*}{ Macroclymene zonalis $(\mathrm{P})$} & \multirow[t]{2}{*}{$970(447)$} & \multirow[t]{2}{*}{$\mathrm{TI}$} & $\mathrm{Sp}$ & 771 & $5-10$ & $0-15$ & \multirow[t]{2}{*}{1} \\
\hline & & & $\mathrm{F}$ & 426 & $2-10$ & $0-15$ & \\
\hline \multirow{2}{*}{ Paraprionospio pinnata $(\mathrm{P})$} & \multirow[t]{2}{*}{$533(358)$} & \multirow[t]{2}{*}{ TI } & $\mathrm{Sp}$ & 159 & $0-2$ & $0-2$ & \multirow[t]{2}{*}{2} \\
\hline & & & $\mathrm{F}$ & 421 & $0-2$ & $0-10$ & \\
\hline \multirow[t]{2}{*}{ Bhawania heteroseta $(\mathrm{P})$} & \multirow[t]{2}{*}{$267(285)$} & \multirow[t]{2}{*}{ B } & $\mathrm{Sp}$ & 208 & $5-10$ & $0-15$ & \multirow[t]{2}{*}{4} \\
\hline & & & $\mathrm{F}$ & 128 & $5-10$ & $0-10$ & \\
\hline \multirow[t]{2}{*}{ Nephtys spp. juv. (P) } & \multirow[t]{2}{*}{$241(253)$} & \multirow[t]{2}{*}{$\mathrm{B}$} & $\mathrm{Sp}$ & 196 & $0-2$ & $0-2$ & \multirow[t]{2}{*}{3} \\
\hline & & & $\mathrm{F}$ & 16 & $0-2$ & $0-10$ & \\
\hline \multirow[t]{2}{*}{ Sigambra tentaculata $(\mathrm{P})$} & \multirow[t]{2}{*}{$239(203)$} & \multirow[t]{2}{*}{ B } & $\mathrm{Sp}$ & 109 & $5-10$ & $0-15$ & 4 \\
\hline & & & $F$ & 89 & $2-5$ & $0-15$ & \\
\hline Notomastus latericeus (P) & $179(317)$ & BS & $\mathrm{Sp}$ & 155 & $2-5$ & $0-1.0$ & 1 \\
\hline & & & $\mathrm{F}$ & 28 & $5-10$ & $2-15$ & \\
\hline Nephtys cf. cryptomma (P) & $131(117)$ & $\mathrm{B}$ & $\mathrm{Sp}$ & 37 & $0-2$ & $0-10$ & 3 \\
\hline & & & $\mathrm{F}$ & 38 & $2-5$ & $0-15$ & \\
\hline Macoma tenta (B) & $110(103)$ & B & $\mathrm{Sp}$ & 31 & $0-2$ & $0-5$ & 3 \\
\hline & & & $F$ & 17 & $0-2$ & $0-10$ & \\
\hline Podarkeopsis levifuscina (P) & $97 \quad(75)$ & $\mathrm{B}$ & $\mathrm{Sp}$ & 78 & $5-10$ & $0-15$ & 4 \\
\hline & & & $\mathrm{F}$ & 21 & $2-5$ & $0-10$ & \\
\hline Idunella barnardi $(\mathrm{A})$ & $90(104)$ & $\mathrm{C}$ & $\mathrm{Sp}$ & 69 & $0-2$ & $0-10$ & 5 \\
\hline & & & $F$ & 30 & $0-2$ & $0-10$ & \\
\hline Ampelisca spp. (abdita or vadorum) (A) & $78 \quad(62)$ & $\mathrm{TI}$ & $\mathrm{Sp}$ & 26 & $0-2$ & $0-2$ & 2 \\
\hline & & & $F$ & 34 & $0-2$ & $0-5$ & \\
\hline Loimia medusa $(\mathrm{P})$ & $68(68)$ & TI & $\mathrm{Sp}$ & 22 & $2-5$ & $0-10$ & 1 \\
\hline & & & $\mathrm{F}$ & 66 & $2-5$ & $0-10$ & \\
\hline Tubulanus pellucidus (N) & $65 \quad(62)$ & $E, B$ & $\mathrm{Sp}$ & 41 & $0-2$ & $0-2$ & 5 \\
\hline & & & F & 24 & $0-2$ & $0-10$ & \\
\hline Chaetopterus variopedatus (P) & $63 \quad(91)$ & TI & $\mathrm{Sp}$ & 37 & $5-10$ & $0-15$ & 1 \\
\hline & & & F & 22 & $2-5$ & $0-15$ & \\
\hline Glycinde solitaria $(\mathrm{P})$ & $57 \quad(57)$ & B & $\mathrm{Sp}$ & 38 & $0-2$ & $0-2$ & 3 \\
\hline & & & $F$ & 67 & $0-2$ & $0-5$ & \\
\hline Pseudeurythoe paucibranchiata (P) & $54 \quad(93)$ & B & $\mathrm{Sp}$ & 24 & $10-15$ & $0-15$ & 4 \\
\hline & & & F & 23 & $5-10$ & $5-15$ & \\
\hline Cirratulidae (P) (cf. Tharyx) & $48 \quad(66)$ & $\mathrm{U}$ & $\mathrm{Sp}$ & 21 & $5-10$ & $0-15$ & 4 \\
\hline & & & $\mathrm{F}$ & 34 & $5-10$ & $2-15$ & \\
\hline Acteocina canaliculata (G) & $48 \quad(46)$ & $B, S$ & $\mathrm{Sp}$ & 78 & $0-2$ & $0-2$ & 3 \\
\hline & & & F & 40 & $0-2$ & $0-5$ & \\
\hline Glycera americana $(\mathrm{P})$ & $46 \quad(43)$ & B & $\mathrm{Sp}$ & 31 & $5-10$ & $0-10$ & 3 \\
\hline & & & $E$ & 17 & $0-2$ & $2-15$ & \\
\hline Polydora comuta $(\mathrm{P})$ & $41 \quad(86)$ & TE & $\mathrm{Sp}$ & 125 & $0-2$ & $0-2$ & 5 \\
\hline & & & $\mathrm{F}$ & 2 & $0-2$ & $0-2$ & \\
\hline Mytilus edulss (B) & $39(150)$ & E & $S p$ & 511 & $0-2$ & $0-2$ & 5 \\
\hline & & & $\mathrm{F}$ & np & & & \\
\hline Macoma spp. juv. (B) & $37 \quad(72)$ & B & $\mathrm{Sp}$ & 10 & $0-2$ & $0-2$ & 3 \\
\hline & & & $\mathrm{F}$ & $n p$ & & & \\
\hline Mediomastus ambiseta (P) & $38 \quad(58)$ & TI & $\mathrm{Sp}$ & 32 & $0-2$ & $0-2$ & 2 \\
\hline & & & $\mathrm{F}$ & 49 & $0-2$ & $0-5$ & \\
\hline Yoldia limatula (B) & $35 \quad(60)$ & $B$ & $\mathrm{Sp}$ & 75 & $0-2$ & $0-5$ & 3 \\
\hline & & & $\mathrm{F}$ & 10 & $0-2$ & $0-5$ & \\
\hline Polycladia & $34 \quad(37)$ & $E, B$ & $\mathrm{Sp}$ & 23 & $0-2$ & $0-10$ & 5 \\
\hline & & & $\mathrm{F}$ & 21 & $2-5$ & $0-10$ & \\
\hline Idunella clymenellae (A) & $33(40)$ & C & $\mathrm{Sp}$ & 27 & $0-2$ & $0-10$ & 5 \\
\hline & & & F & 42 & $2-5$ & $0-10$ & \\
\hline
\end{tabular}


Table 1 (continued)

\begin{tabular}{|c|c|c|c|c|c|c|c|c|}
\hline \multirow{2}{*}{$\begin{array}{l}\text { Taxon } \\
\text { Anachis lafresnayi }(G)\end{array}$} & \multicolumn{2}{|c|}{$\begin{array}{l}\text { Grand } \\
\text { mean } \\
\text { ind. } m^{-2}\end{array}$} & \multirow{3}{*}{$\begin{array}{c}\text { Living } \\
\text { position } \\
\text { E, S }\end{array}$} & \multirow{3}{*}{$\begin{array}{l}\text { Cruise } \\
\text { Sp } \\
\text { F }\end{array}$} & \multirow{2}{*}{$\begin{array}{l}N \\
\\
27\end{array}$} & \multirow{2}{*}{$\begin{array}{l}\text { Modal } \\
\text { depth } \\
(\mathrm{cm})\end{array}$} & \multirow{2}{*}{$\begin{array}{c}\text { Depth } \\
\text { range } \\
(\mathrm{cm})\end{array}$} & \multirow{2}{*}{$\begin{array}{c}\text { Group } \\
5\end{array}$} \\
\hline & 29 & $(44)$ & & & & & & \\
\hline & & & & & 6 & $0-5$ & $0-5$ & \\
\hline \multirow[t]{2}{*}{ Clymenella torquata (P) } & 24 & (29) & TI & Sp & 25 & $5-10$ & $0-15$ & 1 \\
\hline & & & & F & 45 & $5-15$ & $2-15$ & \\
\hline \multirow[t]{2}{*}{ Erichthonius brasiliensis (A) } & 23 & $(71)$ & TE & $\mathrm{Sp}$ & 11 & $0-2$ & $0-2$ & 5 \\
\hline & & & & $\mathrm{F}$ & 11 & $0-2$ & $0-2$ & \\
\hline \multirow[t]{2}{*}{ Phoronis sp. (PH) } & 23 & $(26)$ & TI & $\mathrm{Sp}$ & 6 & $0-2$ & $0-5$ & 2 \\
\hline & & & & $\mathrm{F}$ & 22 & $2-5$ & $0-5$ & \\
\hline \multirow[t]{2}{*}{ Pectinaria gouldi $(\mathrm{P})$} & 22 & $(85)$ & TI & $S p$ & 6 & $0-2$ & $0-5$ & 3 \\
\hline & & & & F & 10 & $0-2$ & $0-5$ & \\
\hline \multirow[t]{2}{*}{ Turbonilla interrupta (G) } & 20 & (29) & $\mathrm{S}$ & $\mathrm{Sp}$ & 25 & $0-2$ & $0-5$ & 3 \\
\hline & & & & $\mathrm{F}$ & 11 & $0-2$ & $0-5$ & \\
\hline \multirow{2}{*}{ Malmgreniella sp. A (P) } & 19 & $(24)$ & $\mathrm{C}$ & $\mathrm{Sp}$ & 27 & $0-2$ & $0-10$ & 5 \\
\hline & & & & $\mathrm{F}$ & 20 & $5-10$ & $0-15$ & \\
\hline \multirow[t]{2}{*}{ Microphiopholis atra E) } & 19 & $(21)$ & BS & $\mathrm{Sp}$ & 13 & $0-2$ & $0-10$ & 1 \\
\hline & & & & $F$ & 16 & $5-10$ & $2-15$ & \\
\hline \multirow[t]{2}{*}{ Mulinia lateralis (B) } & 18 & (63) & B & $\mathrm{Sp}$ & 43 & $0-2$ & $0-5$ & 3 \\
\hline & & & & F & 2 & $0-2$ & $0-2$ & \\
\hline \multirow[t]{2}{*}{ Owenia fusiformis (P) } & 15 & (17) & $\mathrm{TI}$ & $\mathrm{Sp}$ & 19 & $0-2$ & $0-5$ & 2 \\
\hline & & & & $\mathrm{F}$ & 12 & $0-2$ & $0-5$ & \\
\hline \multirow[t]{2}{*}{ Tubificoides spp. (O) } & 15 & $(25)$ & $\mathrm{B}$ & $\mathrm{Sp}$ & 65 & $0-2$ & $0-5$ & 3 \\
\hline & & & & $\mathrm{F}$ & 18 & $0-2$ & $0-5$ & \\
\hline \multirow[t]{2}{*}{ Nereis succinea $(\mathrm{P})$} & 13 & (21) & $E, B$ & $\mathrm{Sp}$ & $\mathrm{np}$ & & & \\
\hline & & & & $\mathrm{F}$ & 31 & $0-2$ & $0-10$ & 5 \\
\hline Corophium tuberculatum (A) & 13 & $(32)$ & TE & $\mathrm{Sp}$ & 19 & $0-2$ & $0-2$ & \\
\hline & & & & $\mathrm{F}$ & 12 & $0-2$ & $0-5$ & 5 \\
\hline Odostomia cf. engonia $(\mathrm{G})$ & 13 & (29) & $E, S$ & $\mathrm{Sp}$ & np & & & \\
\hline & & & & $\mathrm{F}$ & 101 & $0-2$ & $0-2$ & 5 \\
\hline Balanoglossus sp. $(\mathrm{H})$ & 12 & $(20)$ & BS & $\mathrm{Sp}$ & 14 & $2-5$ & $0-15$ & \\
\hline & & & & $F$ & 5 & $10-15$ & $0-15$ & 1 \\
\hline Ampelisca verrilli $(\mathrm{A})$ & 11 & (21) & TI & $\mathrm{Sp}$ & 1 & $0-2$ & $0-2$ & \\
\hline & & & & $\mathrm{F}$ & 4 & $2-5$ & $0-5$ & 2 \\
\hline Cabira incerta $(\mathrm{P})$ & 10 & $(22)$ & B & $\mathrm{Sp}$ & 4 & $5-10$ & $2-15$ & \\
\hline & & & & $\mathrm{F}$ & 10 & $5-15$ & $0-15$ & 4 \\
\hline Cylichna alba $(G)$ & 9 & (14) & B, S & $\mathrm{Sp}$ & 21 & $0-2$ & $0-2$ & 3 \\
\hline & & & & $\mathrm{F}$ & 16 & $0-2$ & $0-2$ & \\
\hline Asychis elongata $(\mathrm{P})$ & 9 & $(11)$ & $\mathrm{TI}$ & $\mathrm{Sp}$ & 8 & $10-15$ & $0-15$ & 1 \\
\hline & & & & $\mathrm{F}$ & 6 & $10-15$ & $2-15$ & \\
\hline Molgula manhattensis $(\mathrm{U})$ & 8 & (25) & $E$ & $S p$ & 1 & $0-2$ & $0-2$ & 5 \\
\hline & & & & $\mathrm{F}$ & 1 & $0-2$ & $0-2$ & \\
\hline Prionospio perkinsii $(\mathrm{P})$ & 8 & $(25)$ & $\mathrm{U}$ & $\mathrm{Sp}$ & 8 & $5-10$ & $0-15$ & 3 \\
\hline & & & & $\mathrm{F}$ & 22 & $2-5$ & $0-15$ & \\
\hline Micrura sp. (N) & 8 & (14) & $\mathrm{B}$ & $\mathrm{Sp}$ & 4 & $2-5$ & $0-15$ & 3 \\
\hline & & & & $F$ & 3 & $2-5$ & $0-15$ & \\
\hline Gyptis vittata $(\mathrm{P})$ & 7 & $(20)$ & B & $\mathrm{Sp}$ & 9 & $5-10$ & $5-15$ & 4 \\
\hline & & & & $\mathrm{F}$ & 13 & $0-2$ & $0-15$ & \\
\hline Ceriantheopsis americanus (AN) & 7 & (13) & $\mathrm{TI}$ & Sp & 6 & $0-2$ & $0-15$ & 1 \\
\hline & & & & $\mathrm{F}$ & 12 & $5-10$ & $0-10$ & \\
\hline Mean density - 50 dominants & 3994 & $(1630)$ & & & & & & \\
\hline Grand mean density - total fauna & 4195 & $(1683)$ & & & & & & \\
\hline
\end{tabular}

Species distribution and abundance patterns were evaluated around organisms that produced the most commonly observed biogenic structures at the sediment-water interface (the tube tops of Chaetopterus variopedatus and fecal coils surrounding tube tops of Macroclymene zonalis). During June 1984 patterns of faunal distribution directly around and near to (see below) the tubes of C. variopedatus and around and 
Table 2. Percent significant Pearson product-moment correlations $(p<0.05)$ among groups of species.,+- : positive and negative correlations, respectively; n: number of pairwise comparisons for those groups. Group membership for dominant species is as given in Table 1 See text for further explanation

\begin{tabular}{|c|c|c|c|c|c|}
\hline Group & $\begin{array}{c}\text { (1) } \\
\text { Large tubet } \\
\text { burrow builders }\end{array}$ & $\begin{array}{l}\text { (2) } \\
\text { Small tube } \\
\text { builders }\end{array}$ & $\begin{array}{c}\text { (3) } \\
\text { Shallow } \\
\text { burrowers }\end{array}$ & $\begin{array}{c}\text { (4) } \\
\text { Deep } \\
\text { burrowers }\end{array}$ & $\begin{array}{c}\text { (5) } \\
\text { Epifaunat } \\
\text { commensals }\end{array}$ \\
\hline & $+\quad-$ & $+\quad-$ & - & +- & $+\quad-$ \\
\hline (1) & $\begin{array}{r}33 \\
n=36\end{array}$ & $\begin{array}{rr}11 & 6 \\
\mathrm{n} & =54\end{array}$ & $\begin{array}{lr}18 & 2 \\
\mathrm{n} & =135\end{array}$ & $\begin{array}{lr}38 & 0 \\
\mathrm{n}_{1}= & 63\end{array}$ & $\begin{array}{lr}16 & 2 \\
\mathrm{n}=117\end{array}$ \\
\hline (2) & & $\begin{array}{lr}7 & 0 \\
\mathrm{n} & =15\end{array}$ & $\begin{array}{l}16 \\
\mathrm{n}=90\end{array}$ & $\begin{array}{cr}5 & 2 \\
n= & 42\end{array}$ & $\begin{array}{lr}19 & 1 \\
\mathrm{n} & =78\end{array}$ \\
\hline (3) & & & $\begin{array}{lr}19 & 3 \\
\mathrm{n} & =105\end{array}$ & $\begin{array}{lr}25 & 1 \\
\mathrm{n}=105\end{array}$ & $\begin{array}{lr}18 & 3 \\
n & =195\end{array}$ \\
\hline (4) & & & & $\begin{array}{lr}53 & 0 \\
\mathrm{n}= & 21\end{array}$ & $\begin{array}{lr}15 & 0 \\
n= & 91\end{array}$ \\
\hline (5) & & & & & $\begin{array}{lr}15 & 1 \\
\mathrm{n}= & 78\end{array}$ \\
\hline
\end{tabular}

near to the active tubes of $M$. zonalis (as determined by the presence of a fecal coil) were determined by comparison of diver-collected pairs of small cores $12.5 \mathrm{~cm}$ diameter taken to a depth of $5 \mathrm{~cm}$ ) at the station indicated in Fig. 1. Core samples around tubes were taken by inserting a core tube down into the sediment so that it included the tube of one of these species (referred to subsequently as the 'with core'). Before the first core was removed, a second core was inserted into the sediment adjacent to the first into an area that did not contain tubes to obtain a sample near to the tube (the 'without core') then both cores were capped and removed from the sediment. Further resolution of faunal patterns in association with $C$. variopedatus tubes were made at the same site during June 1985 when tubes were partitioned ('partitioned samples') by separating the section of tube projecting above the sediment surface (above interface') from the portion extending from the surface to a depth of $5 \mathrm{~cm}$ ('below interface'), to determine if organisms associated with the tube were living above or below the sedimentwater interface.

Functional characteristics or life habits of macrobenthic ( $\geqslant 250 \mu \mathrm{m}$ ) fauna collected from all samples taken within the Wolf Trap study area between 1983 and 1986 were determined from shipboard core dissections (as noted above), in situ field observations, observations of live specimens maintained in laboratory aquaria or reference to studies previously published in the literature.

Diversity measures were computed for 'paired' core sample collections (associated with Chaetopterus variopedatus and Macroclymene zonalis tubes) using formulas given by Margalef (1958) and Pielou (1966), assuming that these collections represent samples of a community that was not fully censused (Pielou 1966). This assumption was made since there is no evidence that all fauna associated with tube structures are restricted to a single tube (e.g. organisms may or may not move between adjacent tubes). Mean faunal abundances and diversity measures between 'paired' core samples were compared using Student's t-test after ensuring that the data met the assumptions as given in Sokal \& Rohlf (1969). Associations between species were evaluated by pairwise comparisons of abundance data from box core collections for selected groups of species using Pearson product-moment correlation. All statistics except diversity measures were computed using the SPSSX statistical package (SPSS Inc. 1983).

\section{RESULTS}

A total of 135 species were collected at the Wolf Trap area during this study". A subset of 50 taxa, most identified to the species level, accounted for $95 \%$ of the total fauna in quantitative box core samples (Table 1 ). These taxa are hereafter referred to as the 'dominant' fauna. Based on living position and habits and depth distribution patterns (Table 1), the dominant fauna can be divided into 5 functional groups: (1) large, tube and burrow builders with modal depth distributions below $2 \mathrm{~cm}$ and depth ranges extending below $10 \mathrm{~cm}$; (2) small, tube builders with modal depth distributions above $2 \mathrm{~cm}$ and depth ranges generally not extending

\footnotetext{
- A full listing of the species collected, with functional characteristics and distributional information, is available from the author on request
} 
below $5 \mathrm{~cm}$; (3) shallow burrowers with modal depth distributions above $2 \mathrm{~cm}$ and depth ranges generally not extending below $10 \mathrm{~cm}$; (4) deep burrowers with modal depth distributions below $2 \mathrm{~cm}$ and depth ranges extending below $10 \mathrm{~cm}$; (5) epifauna and tube or burrow co-inhabitants.

The results of pairwise comparisons of dominant species abundances, by functional groups as listed above (Table 1), are summarized in Table 2 . Positive correlations in pairwise comparisons will result if species abundance patterns are coincident. Negative correlations should result if species interactions lead to

\section{SEDIMENT HORIZON}

$02 \mathrm{~cm}$

$2 \cdot 4 \mathrm{~cm}$

TUBES
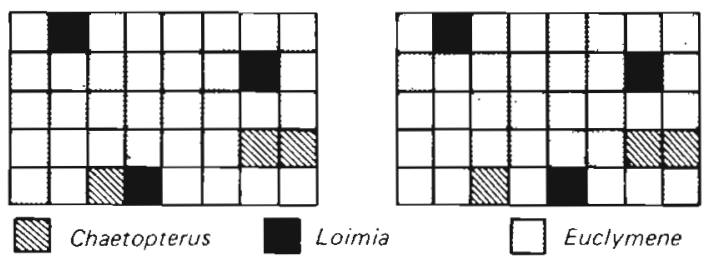

TOTAL FAUNA

\begin{tabular}{|c|c|c|c|c|c|c|c|}
\hline 10 & 8 & 9 & 4 & 9 & 9 & 7 & 9 \\
\hline 5 & 4 & 11 & 10 & 14 & 5 & 15 & \\
\hline 2 & 6 & 7 & 14 & 8 & 10 & 11 & 6 \\
\hline 2 & 1 & 3 & 15 & 8 & 8 & 12 & 12 \\
\hline 9 & 2 & 35 & 53 & 12 & & 3 & 8 \\
\hline
\end{tabular}$\quad$\begin{tabular}{|c|c|c|c|c|c|c|c|}
5 & 2 & 1 & 5 & & 1 & 3 & \\
\hline 2 & & 2 & 3 & 1 & 3 & 1 & 3 \\
\hline & 1 & & 1 & & 3 & 4 & \\
\hline 2 & 1 & 4 & 7 & 3 & 3 & 2 & 1 \\
\hline 1 & 2 & 7 & 9 & 1 & & 2 & 2 \\
\hline
\end{tabular}

Polvdora cornuta

\begin{tabular}{|l|l|l|l|l|l|l|l|}
\hline 1 & & 4 & & 3 & 3 & 1 & 5 \\
\hline & & 2 & & 5 & 2 & 8 & \\
\hline & 1 & 2 & 13 & 3 & 1 & 2 & \\
\hline & & & 9 & 2 & 2 & 7 & 9 \\
\hline 6 & 2 & 27 & 23 & 3 & & & \\
\hline
\end{tabular}

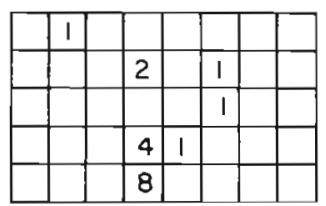

Corophium tuberculatum
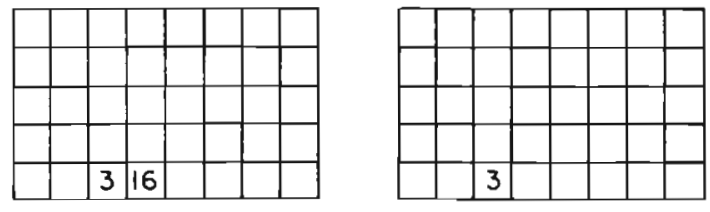

Mediomastus ambiseta

\begin{tabular}{|l|l|l|l|l|l|l|l|}
\hline 2 & 1 & 3 & & 1 & & 1 & 1 \\
\hline 2 & 2 & 4 & 6 & 3 & 1 & & \\
\hline 2 & 3 & 1 & & & 4 & 3 & 2 \\
\hline 2 & & 1 & & 2 & 1 & 2 & \\
\hline & & 2 & 9 & 4 & & & 2 \\
\hline
\end{tabular}

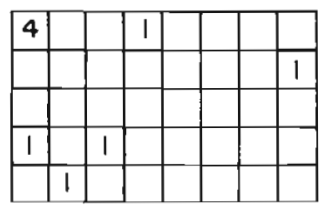

Fig. 3. Spatial patterns of selected species in 'core array' samples. Cores containing tubes of large macrofauna are shaded spacing patterns that are resolvable at the scales sampled. For all comparisons, significant $(p<0.05)$ negative correlations were rare. Of the 1225 total pairwise comparisons possible, only $1.7 \%$ were significantly negative (actual range by group was 0 to $6 \%$; see Table 2). Positive correlations were more common, accounting for $19.3 \%$ (actual range by group was 5 to $52 \%$ ) of all pairwise comparisons. Highest percentages of positive correlations were observed for pairwise comparisons within Group 4 species (deep burrowers) $(52 \%)$ and between Group 4 species and Group 1 species (large tube and burrow builders) (38\%). Highest percentages of negative correlations were observed for comparisons between Group 2 species (small tube builders) and Group 1 species (6\%).

Distribution of organisms $\geq 250 \mu \mathrm{m}$ and tube-builders in a single vertically and horizontally subsectioned box core that contained tubes of the polychaetes Chaetopterus variopedatus, Loimia medusa and Macroclymene zonalis is shown in Fig. 3. Organism density was highest near the surface (i.e. $81 \%$ of total fauna in the $0-2 \mathrm{~cm}$ layer) relative to the deeper $2-4 \mathrm{~cm}$ sampling horizon. Small tube-builders (the polychaete Polydora cornuta and amphipod Corophium tuberculatum) were most abundant in these 'core array' samples when individual cores contained either a $C$. variopedatus or a $L$. medusa tube, while some organisms encountered in the arrays (e.g. the infaunal polychaete Mediomastus ambiseta) did not exhibit patterns easily related to tube structures. Tubes of $M$. zonalis were present in nearly every subsection, making it difficult to discern patterns relating to its presence or absence.

Discrete sampling of the most common structures at the sediment surface (i.e. Chaetopterus variopedatus tube tops and Macroclymene zonalis fecal coils) showed that the polychaetes Streblospio benedicti, Nereis succinea and Polydora cornuta, amphipod Corophium tuberculatum and an unindentified nemertean were significantly more abundant in or limited to the cores containing $C$. variopedatus tubes (Table 3 ). With the exception of Mediomastus ambiseta, most abundant species associated with $C$. variopedatus were found on the exposed tube tops rather than in the surrounding sediments (Table 4). No species were found to exhibit significant differences in abundance in surface sediments around or near to $M$. zonalis tubes (Table 3).

No significant differences in the measures of diversity, evenness and richness were observed for comparisons between those samples with and without Macroclymene zonalis tubes (Table 5). Conversely, numbers of individuals, species and $\mathrm{H}^{\prime}$ diversity were significantly greater in samples with Chaetopterus variopedatus tubes than in those without tubes. 
Table 3. Comparisons of organism densities in 'paired' core samples which included (with) or excluded (without) tubes of Chaetopterus variopedatus and Macroclymene zonalis. Cores were $2.5 \mathrm{~cm}$ in diameter and were taken to a depth of $5 \mathrm{~cm}$. Only species meeting assumptions for $\mathrm{t}$ - or Mann-Whitney $\mathrm{U}$ tests are listed

\begin{tabular}{|c|c|c|c|c|c|}
\hline Comparison/taxon & $\begin{array}{c}\text { With } \\
\bar{X}(\mathrm{SD})\end{array}$ & $\begin{array}{l}\text { Without } \\
\overline{\mathrm{X}}(\mathrm{SD})\end{array}$ & $\mathrm{t}$ & U & $\mathrm{p}$ \\
\hline \multicolumn{6}{|c|}{ Chaetopterus variopedatus (No. of pairs $=20$ ) } \\
\hline Total fauna & $43(45)$ & $16 \quad(9)$ & 3.86 & & $<0.001$ \\
\hline Crustacea & $24(35)$ & $6 \quad(4)$ & 4.26 & & $<0.001$ \\
\hline Annelida & $14(11)$ & $9 \quad(5)$ & ns & & \\
\hline Mollusca & $1(2)$ & $<1(<1)$ & & 104 & 0.02 \\
\hline Misc taxa & $4(5)$ & 2 (2) & ns & & \\
\hline Corophium tuberculatum & $10(10)$ & $<1 \quad$ (1) & & 29 & $<0.01$ \\
\hline Streblospio benedicti & $8(23)$ & $<1 \quad$ (1) & & 83 & $<0.01$ \\
\hline Polydora cornuta & $4(4)$ & $<1(<1)$ & & 46 & $<0.01$ \\
\hline Nemertea sp. 2 & $3(4)$ & $<1 \quad$ (1) & & 100 & 0.02 \\
\hline Nereis succinea & $2(5)$ & 0 & 2.32 & & 0.03 \\
\hline Mediomastus ambiseta & $4 \quad(4)$ & $5 \quad(3)$ & ns & & \\
\hline Ampelisca abdita & $5(4)$ & $5 \quad(4)$ & ns & & \\
\hline Nemertea sp. 1 & $1(1)$ & $1 \quad(2)$ & ns & & \\
\hline Tubificoides spp. & $1(3)$ & $1(1)$ & & ns & \\
\hline \multicolumn{6}{|c|}{ Macroclymene zonalis ( No. of pairs $=11$ ) } \\
\hline Total fauna & $18(7)$ & $19 \quad(6)$ & ns & & \\
\hline Annelida & 10 & $12(6)$ & ns & & \\
\hline Mollusca & $5 \quad(3)$ & $6 \quad(3)$ & ns & & \\
\hline Misc. taxa & $2(2)$ & 1 (1) & ns & & \\
\hline Crustacea & $1(1)$ & $1 \quad(1)$ & ns & & \\
\hline Mediomastus ambiseta & $5 \quad(3)$ & $5 \quad\{3\}$ & ns & & \\
\hline Ampelisca abdita & $5(2)$ & $5 \quad(3)$ & ns & & \\
\hline Streblospio benedicti & $2(1)$ & 3 (2) & ns & & \\
\hline Nemertea sp. 2 & 1 (2) & 0 & ns & & \\
\hline Tubificoides spp. & 1 (2) & $1 \quad(2)$ & ns & & \\
\hline Pectinaria gouldii & $<1 \quad$ (1) & $1 \quad(2)$ & ns & & \\
\hline
\end{tabular}

\section{DISCUSSION}

This study demonstrates a high degree of association among some species within an estuarine community. At the small scales studied (i.e. centimeters to decimeters) positive associations among species were more common than negative associations.

Positive associations between Chaetopterus variopedatus and other species, especially epifauna, enhanced species richness and diversity in this community. Associations between large tube builders and smaller infaunal species are well documented in softbottom benthic communities. Enhanced infaunal abundance in the presence of larger tube builders has been explained as a function of predation pressure and the availability of refugia (Woodin 1978, 1981), hydrodynamics governing the settlement of larvae (Eckman 1979) and active habitat selection by larvae and juveniles keyed to sediment amelioration or stabilization by adults (Reise 1981, 1985, Gallagher et al. 1983). For this study, changes in faunal abundance and a resultant increases in species diversity in association with C. variopedatus was driven primarily by changes in the abundance of epifaunal species, suggesting that habitat availability is increased for species requiring firm substrate in an area otherwise characterized by fine-grained sediments. Changes in organism abundance and diversity as a function of habitat complexity or heterogeneity have been demonstrated for a wicle variety of terrestrial and aquatic habitats (Bell 1985 and references contained therein). A seemingly important point for this study is that alterations in habitat quality or availability are governed by the presence or absence of an organism, rather than by some physical feature of the environment.

Infaunal depth distribution patterns show that many of the small deep burrowers common at the Wolf Trap site (e.g. Bhawania heteroseta and Sigambra tentaculata) were most abundant below $5 \mathrm{~cm}$ in the sediment column, an area where oxygenated voids associated with the feeding activities of the head-down deposit-feeding maldanids Macroclymene zonalis and Clymenella torquata generally formed a sponge-like network in subsurface sediments (e.g. Fig. 2b; Diaz et al. 1985). Tube and burrow structures and feeding voids are known to act as localized sites of enhanced 
Table 4. Comparision of organism densities in association with Chaetopterus variopedatus tubes. Samples were obtained by partitioning the portion of a tube projecting above the sediment-water interface from the portion contained in a $2.5 \mathrm{~cm}$ diameter core tube taken to a depth of $5 \mathrm{~cm}$ below the interface. No. of partitioned samples $=9$

\begin{tabular}{|c|c|c|c|c|}
\hline \multirow{2}{*}{$\begin{array}{l}\text { Species } \\
\text { Corophium tuberculatum }\end{array}$} & \multicolumn{2}{|c|}{$\begin{array}{c}\text { Above } \\
\text { interface } \\
\bar{X}(S D)\end{array}$} & \multicolumn{2}{|c|}{$\begin{array}{c}\text { Below } \\
\text { interface } \\
\bar{X}(S D)\end{array}$} \\
\hline & 70 & $(58)$ & 6 & (7) \\
\hline Erichthonius brasiliensis & 40 & (53) & 0 & \\
\hline Polydora cornuta & 10 & (14) & 1 & (3) \\
\hline Caprellidae & 5 & (14) & 1 & (1) \\
\hline Parametopella cypris & 5 & (11) & 1 & (2) \\
\hline Nereis succinea & 3 & (4) & 2 & (3) \\
\hline Amphipoda juveniles & 2 & (4) & 0 & \\
\hline Molgula manhattensis & 2 & (3) & $<1$ & (1) \\
\hline Monoculodes sp. & $<1$ & $(<1)$ & 0 & \\
\hline Sabellidae & $<1$ & $(<1)$ & 0 & \\
\hline Mediomastus ambiseta & 0 & & 55 & $(45)$ \\
\hline Streblospio benedicti & $<1$ & $(<1)$ & 3 & (3) \\
\hline Ampelisca abdita & $<1$ & (1) & 2 & (3) \\
\hline Macroclymene zonalis & $<1$ & (1) & 1 & (2) \\
\hline Bivalvia juveniles & 0 & & 1 & (1) \\
\hline Tubificoides spp. & 0 & & $<1$ & (1) \\
\hline Rhynchocoela juveniles & 0 & & $<1$ & (1) \\
\hline Gastropoda juveniles & 0 & & $<1$ & (1) \\
\hline Hesionidae juveniles & 0 & & $<1$ & (1) \\
\hline Heteromastus filiformis & 0 & & $<1$ & $(<1)$ \\
\hline Owenia fusiformis & 0 & & $<1$ & $(<1)$ \\
\hline Asabellides oculata & 0 & & $<1$ & $(<1)$ \\
\hline Amphiporus bioculatus & 0 & & $<1$ & $(<1)$ \\
\hline Nephtys sp juveniles & 0 & & $<1$ & $(<1)$ \\
\hline
\end{tabular}

microfaunal and meiofaunal activity (Reise 1981, 1985, Aller \& Aller 1986), but their roles in promoting macrofaunal abundance have generally not been considered. Positive correlations between small, deep-burrowing macrofaunal species (most of which appear to be predators; Fauchald \& Jumars 1979) and large macrofauna which create subsurface biogenic structure suggest additional examples of positive interactions in this soft-bottom community.

Among the dominants in this estuarine community were some infaunal species (e.g. the small tube builders Paraprionospio pinnata, Ampelisca abdita, and Mediomastus ambiseta and shallow burrower Glycinde solitaria) that have previously been characterized as 'euryhaline opportunists' (sensu Boesch 1977). These species are widely distributed and abundant throughout the estuarine mesohaline zone on a wide range of bottom types (e.g. Holland et al. 1987, Schaffner et al. 1987b). Based on data from Chesapeake Bay and the York River tributary, Boesch (1977) and others (Boesch et al. 1976a,b) suggested that 'euryhaline opportunists' and larger, longer-living 'equilibrium' species generally do not coexist in estuarine benthic communities. Exclusion of some species from the Wolf Trap assemblage might be predicted on the basis of functional group interactions since both laboratory and field experiments (e.g. Brenchley 1981) demonstrate that sediment disturbance by bioturbators (some of the larger species in the present study, especially the maldanid polychaetes) results in significant mortality of small tube-builders (most of the euryhaline opportunists in the present study). Large tube and burrow builders and small tube builders exhibited the highest percentage of negative correlations during this study, however both groups included species that were dominant at the study area. This suggests that functional group amensalism was not a strong force structuring this community, but may influence small-scale patterns of species distribution.

The results of this study indicate that positive associations among species can be common in an estuarine community. These associations are especially evident

Table 5. Summary of diversity measures, numbers of individuals and species and t-test comparisions for 'paired' core samples with and without Chaetopterus variopedatus and Macroclymene zonalis tubes. Values are means with standard deviations given in parentheses

\begin{tabular}{|c|c|c|c|c|c|c|}
\hline & $\begin{array}{l}\text { No. of } \\
\text { cores }\end{array}$ & $\begin{array}{l}\text { No. of } \\
\text { ind. }\end{array}$ & $\begin{array}{l}\text { No. of } \\
\text { spp. }\end{array}$ & $\mathrm{H}^{\prime}$ & $J^{\prime}$ & $\mathrm{SR}$ \\
\hline \multicolumn{7}{|c|}{ Chaetopterus variopedatus } \\
\hline With & 20 & $43(45)$ & $9(3)$ & $2.6(0.4)$ & $0.8(0.1)$ & $2.3(0.6)$ \\
\hline Without & 20 & $16 \quad(9)$ & $7(3)$ & $2.2(0.5)$ & $0.9(0.1)$ & $2.0(0.7)$ \\
\hline t-test & & $<0.01$ & $<0.01$ & 0.01 & ns & ns \\
\hline \multicolumn{7}{|l|}{$\mathrm{p}$} \\
\hline \multicolumn{7}{|c|}{ Macroclymene zonalis } \\
\hline With & 11 & $18(7)$ & $8(3)$ & $2.4(0.6)$ & $0.8(0.1)$ & $2.3(0.8)$ \\
\hline Without & 11 & $19 \quad(6)$ & $7(2)$ & $2.3(0.4)$ & $0.8(0.1)$ & $2.0(0.5)$ \\
\hline \multicolumn{7}{|l|}{ t-test } \\
\hline $\mathrm{p}$ & & ns & $\mathrm{ns}$ & $\mathrm{ns}$ & $\mathrm{ns}$ & ns \\
\hline
\end{tabular}


when evaluated at scales approaching the sizes of the organisms being studied. Identification of numerous positive associations among species and the apparent enhancement of species diversity by positive or promotive species interactions is contrary to the common viewpoint that physical processes and negative interactions govern estuarine community dynamics (see 'Introduction'). Further studies should identify small-scale patterns of species associations and consider the potential for positive or promotive processes when assessing the factors governing estuarine community structure.

Acknowledgements. This work is dedicated to Dr Marvin L Wass for his many contributions to our understanding of Chesapeake Bay fauna. Portions of the study were completed while the author was a doctoral candidate at the School of Marine Science, The College of William and Mary. Support came from the Virqinia Institute of Marine Science, the Baltimore District of the U.S. Army Corps of Engineers (Contract No. DACW-31-C-0041) and the Houston Underwater Club. Special thanks to R. Blama. R. J. Diaz, M. W. Luckenbach and 3 anonymous reviewers provided constructive criticisms of earlier drafts. Thanks also to A. F. Holland for interesting and challenging discussions about Chesapeake Bay. Contribution no. 1582 from the Virginia Institute of Marine Science.

\section{LITERATURE CITED}

Aller, J. Y., Aller, R. C. (1986). Evidence for localized enhancement of biological activity associated with tube and burrow structures in deep-sea sediments at the HEBBLE site, western North Atlantic. Deep Sea Res. 6: 755-790

Bell, S. S. (1985). Habitat complexity of polychaete tube caps: influence of architecture on dynamics of a meioepibenthic assemblage. J. mar. Res. 43: 647-671

Biggs, R. B., Cronin, L. E. (1981). Special characteristics of estuaries. In: Neilson, B. J., Cronin, L. E. (eds.) Estuaries and nutrients. Humana Press, Clifton, New Jersey, p. 3-23

Boesch, D. F. (1977). A new look at the zonation of benthos along the estuarine gradient. In: Coull, B. C. (ed.) Ecology of marine benthos. University of South Carolina Press, Columbia, p. 245-266

Boesch, D. F., Diaz, R. J., Virnstein, R. W. (1976a). Effects of tropical storm Agnes on soft-bottom macrobenthic communities of the James and York estuaries and the lower Chesapeake Bay. Chesapeake Sci. 17: 246-259

Boesch, D. F. Wass, M. L., Virnstein, R. W. (1976b). The dynamics of estuarine benthic communities. In: Wiley, $M$ (ed.) Estuarine processes, I. Uses, stresses and adaptation to the estuary. Academic Press, New York, p. 177-196

Boon, J. D., Bohlen, W. F., Wright, L. D. (1987). Estuarine versus inner shelf disposal sites: a comparison of benthic current regimes. In: Symposium on Coastal Sediment 1987. American Society of Civil Engineers, New Orleans, p. 571-583

Brenchley, G. A. (1981). Disturbance and community structure: an experimental study of bioturbation in marine softbottom environments. J. mar. Res. 39:767-790

Burbanck, W. D., Pierce, M. E., Whiteley, G. C. (1956). A study of the bottom fauna of Rand's Harbor, Massachusetts, and an application of the ecotone eoncept. Ecol. Monogr. 26: $213-243$
Diaz, R. J., Schaffner, L., C. (1988). Comparisons of sediment landscapes in Chesapeake Bay as seen by surface and profile imaging. In: Lynch, M. P., Krome, E. C. (eds.) Understanding the estuary: advances in Chesapeake Bay research. Chesapeake Research Consortium Publ. No. 129. CBP/TRS 24/88, p. 222-240

Diaz, R. J., Schaffner, L. C., Byrne, R. J., Gammisch, R. A. (1985). Baltimore Harbor and channels aquatic benthos investigations. Final Report to the U.S. Army Corps of Engineers, Baltimore District, Baltimore, Maryland, p. $1-255$

Eckman, J. E. (1979). Smal.l-scale patterns and processes in a soft-substratum, intertidal community. J. mar. Res. 37: $437-457$

Elmgren, R., Ankar, S., Marteleur, B., Ejdung, G. (1986). Adult interference with postlarvae in soft sediments: the Pontoporeia-Macoma example. Ecology 67:827-836

Fauchald, K., Jumars, P. A. (1979). The diet of worms: a study of polychaete feeding guilds. Oceanogr. mar. Biol. A. Rev. 16: $19.3-284$

Gainey, L. F. Jr, Greenberg, M. J. (1977). Physiological basis of the species abundance-salinity relationship in molluscs: a speculation. Mar. Biol. 40: 41-49

Gallagher, E. D., Jumars, P. A., Trueblood, D. D. (1983) Facilitation of soft-bottom benthic succession by tube builders. Ecology 64: 1200-1216

Holland, A. F., Mountford, N. K., Heigel, M. H., Kaumeyer, K. R., Mihursky, J. A. (1980). The influence of predation on infaunal abundance in upper Chesapeake Bay. Mar. Biol. 57: $221-235$

Holland, A. F., Shaughnessy, A. T., Heigel. M. H. (1987). Long-term variation in mesohaline Chesapeake Bay macrobenthos: spatial and temporal patterns. Estuaries 10: $227-245$

Josefson, A. B. (1981). Persistence and structure of two deep macrobenthic communities in the Skagerrak (west coast of Swedenl. J. exp. mar. Biol. Ecol. 50: 63-97

Kinne, 0 . (1964). The effects of temperature and salinity on marine and brackish water animals II. Salinity and temperature combinations. Oceanogr mar. Biol. A. Rev. 2: $281-339$

Levinton, J. S. (1982). Marine ecology. Prentice-Hall, Inc., New Jersey

Margalef, R. (1958). Information theory in ecology. Gen. Syst. 3: $36-71$

Peterson, C. H. (1984). Does a rigorous criterion for environmental identity preclude the existence of multiple stable points? Am. Nat. 124:127-133

Pielou, E. C. (1966). The measurement of diversity in different types of biological collections. J. theor, Biol. 13: 131-144

Reinharz, E., Nilsen, K. J., Boesch, D. F., Bertelsen, R., O'Connell, A. E. (1982). A radiographic examination of physical and biogenic sedimentary structures in the Chesapeake Bay. Maryland Geological Survey, Report of Investigations No. 36. The Johns Hopkins University, Baltimore

Reise, K. (1981). High abundances of small zoobenthos around biogenic structures in tidal sediments of the Wadden Sea. Helgoländer Meeresunters. 34: 413-425

Reise, K. (1985). Tidal flat ecology. Springer-Verlag, Berlin

Remane, A, Schlieper, C. (1971). Biology of brackish water. John Wiley and Sons, New York

Ronn, C., Bonsdorff, E., Nelson, W. G. (1988). Predation as a mechanism of interference within infauna in shallow brackish water soft bottoms; experiments with an infauna predator, Nereis diversicolor O. F. Müller. J. exp. mar. Biol. Ecol. 116: 143-157

Sanders, H. L., Mangelsdorf, P. C., Hampson, G. R. (1963). 
Salinity and faunal distribution of the Pocasset River, Massachusetts. Limnol. Oceanogr. 10 (suppl.): 216-229

Santos, S. L., Simon, J. L. (1980). Response of soft-bottom benthos to annual catastrophic disturbance in a south Florida estuary. Mar. Ecol. Prog. Ser. 3: 347-355

Schaffner, L. C., Diaz, R. J., Byrne, R. J. (1987a). Processes affecting recent estuarine stratigraphy. In: Symposium on Coastal Sediment 1987 American Society of Civil Engineers, New Orleans, p. 584-599

Schaffner, L. C., Diaz, R. J., Olsen, C. R., Larsen, I. L. (1987b) Faunal characteristics and sediment accumulation processes in the James River estuary, Virginia. Estuar. cstl Shelf Sci. 25: 211-226

SPSS, Inc. (1983). SPSSX user's guide. McGraw Hill, New York

Sokal, R. R., Rohlf, F. J. (1969). Biometry. W. H. Freeman and Co., San Francisco

Stroup, E. D., Lynn, R. J. (1963). Atlas of salinity and tempera-

This article was submitted to the editor ture distributions in Chesapeake Bay. Chesapeake Bay Institute Report 2, The Johns Hopkins University, Baltimore

Tenore, K. R. (1972). Macrobenthos of the Pamlico river estuary, North Carolina. Ecol. Monogr 42: 51-69

Virnstein, R. W. (1977). The importance of predation by crabs and fishes on benthic infauna in Chesapeake Bay. Ecology 58: 1199-1217

Woodin, S. A. (1978). Refuges, disturbance and community structure: a marine soft-bottom example. Ecology 59: $274-284$

Woodin, S. A. (1981). Disturbance and community structure in a shallow water sand flat. Ecology 62: 1052-1066

Wright, L. D., Prior, D. B., Hobbs, C. H., Byrne, R. J., Boon, J. D., Schaffner, L. C., Green, M. O. (1987). Spatial variability of bottom types in the lower Chesapeake Bay and adjoining estuaries and inner shelf. Estuar cstl Shelf Sci. 24: $765-784$

Manuscript first received: January 18, 1989

Revised version accepted: November 21, 1989 